Didaché: Journal of Christian Education

Vol. 2, No. 1 (2021): 58-72

e-ISSN: 2722-8584

Published by: Sekolah Tinggi Teologi Simpson Ungaran

DOI: $10.46445 /$ djce.v2i1.383

\title{
Nilai Budaya dari Ritual Perkawinan Massarak sebagai Materi Pendidikan Keluarga Kristen di Mamasa
}

\author{
Masdariani Sidu' ${ }^{1}$, Frans Paillin Rumbi ${ }^{2^{*}}$ \\ 1,2 Institut Agama Kristen Negeri Toraja \\ Email: 1masdarianisidu@gmail.com, 2fransrumbi24@gmail.com
}

\begin{abstract}
Generally, Christian education focuses on biblical preaching and church tradition. This method is correct, but it doesn't close the way for other approaches. Christian education can use different strategies to teach the Christian faith. This research focuses on the massarak marriage ritual. The researcher wants to find the cultural values contained in it. The focus of this research is the Mamasa people who live in the Nosu District, Kabupaten Mamasa. Furthermore, the researcher wants to see it from the aspect of Christian education. The authors used qualitative methods to answer the research objectives, namely data collected from observations and interviews, then the data were presented descriptively. The results showed positive values in massarak rituals, namely respect, independence, love, and solidarity. These values can be used in Christian education, of course, in dialogue with the Christian faith.
\end{abstract}

Keywords: Christian education, cultural studies, massarak, Mamasa, wedding

\begin{abstract}
Abstrak
Umumnya pendidikan Kristen fokus pada pemberitaan alkitabiah dan tradisi gereja. Cara ini benar, tetapi bukan berarti menutup jalan atau akhir bagi pendekatan lain. Pendidikan Kristen dapat menggunakan pendekatan lain untuk mengajarkan iman Kristen. Penelitian ini menyoroti ritual perkawinan massarak, peneliti ingin menemukan nilai-nilai budaya yang terkandung di dalamnya. Lokus penelitian ini ialah orang Mamasa yang tinggal di Kecamatan Nosu, Kab. Mamasa. Selanjutnya peneliti hendak melihatnya dari aspek pendidikan Kristen. Penulis menggunakan metode penelitian kualitatif untuk menjawab tujuan penelitian, di mana data dikumpulkan dari hasil observasi dan wawancara, selanjutnya data disajikan secara deskriptif. Hasil penelitian memperlihatkan nilai-nilai positif dalam ritual massarak yakni penghormatan, kemandirian, kasih dan solidaritas. Nilai-nilai tersebut dapat digunakan dalam pendidikan Kristen, tentu saja dalam dialog dengan iman Kristen.
\end{abstract}

Kata Kunci: kajian budaya, Massarak, Mamasa, pendidikan Kristen, perkawinan.

Article History $\quad$ Received: March 7, $2021 \quad$ Revised: May 27, $2021 \quad$ Accepted: June 2, 2021

This is an open access article under the CC BY-SA license 


\section{Pendahuluan}

Tujuan dari pendidikan Kristen ialah mengajarkan supaya semua orang dapat hidup sesuai dengan nilai-nilai Injil Kerajaan Allah. Apabila merujuk kepada perintah mengajar dalam Amanat Agung, maka tugas mengajar harus dilakukan secara kontinu (Tanduklangi, 2020, p. 56). Proses pendidikan atau pengajaran berlangsung pada berbagai sendi hidup serta penting mempertimbangkan konteks yang dihadapi. Antone (2010, p. 8) mengingatkan bahwa konteks memengaruhi proses rancang bangun pendidikan dalam masyarakat. Mempertimbangkan konteks berarti mendengarkan cara masyarakat menghayati kehidupannya baik menyangkut pandangan hidup maupun sistem nilainya.

Konteks Indonesia adalah multikultur baik suku, ras, bahkan identitas keagamaan. Kemajemukan menjadi kekuatan sekaligus tantangan. Tidak jarang perbedaan menjadi sumber konflik, tetapi pada situasi yang lain digemakan keadilan, kesetaraan dan harmoni di tengah perbedaan. Kesadaran atas kemajemukan bukan untuk meniadakan. Susanta (2020, p. 57) mengapresiasi pernyataan The World Council of Churches (WCC) yang mengingatkan supaya gereja memiminalisir berbagi potensi gesekan akibat adanya perbedaan dengan cara mengembangkan pendidikan yang mengedepankan nilai-nilai perdamaian dan persahabatan.

Pada konteks keragaman, pendidikan Kristen diharapkan menggemakan kebenaran dan keadilan, pembebasan, penerimaan, persatuan sebagai perwujudan syalom dari Allah. Namun menurut Susanta, pendidikan agama Kristen yang berlangsung di sekolah seringkali mengarah pada sikap eksklusif dan penyikiran tentang orang yang beragama lain. Pendidikan Kristen dimaknai secara sempit sebagai bagian dari penginjilan atau pengkristenan (Susanta, 2020, p. 60). Untuk menegaskan kondisi ideal, maka pendidikan Kristen perlu menekankan paham-paham teologis yang utama yakni Alkitab dan tradisi Kristen, tetapi pada sisi lain kekristenan perlu menangkap dan mengembangkan nilai-nilai kehidupan dari beragam budaya. Cukup banyak nilai yang dapat digunakan sebagai jalan memperkenalkan iman Kristen. Budaya mengandung nilai-nilai kebersamaan, perdamaian, solidaritas atau kepedulian, ramah tamah dan sebagainya. Salenusa dalam kajiannya tentang cara hidop orang basudara di Ambon, memberi contoh bahwa nilai dalam budaya sejajar dengan nilai kerukunan dan solidaritas pada kitab Mazmur 133 serta pengajaran Yesus Kristus (Salenusa, 2017, p. 172).

Muatan pendidikan Kristen yang berlangsung saat ini sangat menekankan Alkitab dan tradisi Kristen, namun masih kurang mengembangkan para- 
digma reflektif dalam arti menggunakan budaya sebagai cara mengajarkan iman Kristen. Justru sisi negatif dari budaya seringkali dijadikan dasar untuk membenturkannya dengan iman Kristen, akibatnya yang timbul adalah ketegangan. Sidjabat mengingatkan bahaya yang dialami jika pendidikan hanya menekankan sumber alkitabiah dan tradisi Kristen atau sebaliknya hanya menekankan IPTEKS. Terjadi ketidakseimbangan karena yang satu hanya mengutamakan sisi kerohanian, sebaliknya yang lain hanya menekankan sisi akademik (Sidjabat, 2019, p. 16). Sidjabat (2019, p. 18) menegaskan perlunya pendidikan Kristen yang holistik dengan menggunakan pendekatan interdisipliner, multidisipliner. Pendidikan holistik memperlengkapi naradidik dari berbagai aspek seperti metafisik, epistemologi dan aksiologi. Karnawati dan Widodo (2019, p. 84) memberi pandangan terkait pengembangan kurikulum pendidikan Kristen bahwa pengembangan kurikulum perlu memperhatikan landasan teologis maupun interdisipliner seperti psikologi, sejarah, filsafat maupun sosio budaya. Kritik lain dikemukakan oleh Lauterboom (2019, p. 93), menurutnya pendidikan Kristen perlu mengalami dekolonialisasi yakni pembebasan dari kolonialisme yakni dari unsur-unsur normatif di masyarakat yang sifatnya menyengsarakan dan menindas. Proses pendidikan membutuhkan ruang ketiga atau ruang antara bagi refleksi dan aksi pendidikan Kristen. Menurut Lauterboom (2019, p. 105) salah satu usaha dekolonialisasi ialah memberi tempat terhadap narasi budaya lokal untuk perjumpaan yang sakral dengan Tuhan, maupun perjumpaan dengan sesama manusia.

Searah dengan Lauterboom, penulis merasa perlu menemukan ruang alternatif untuk mengajarkan iman Kristen supaya umat dapat merasakan kehadiran Tuhan yang dekat dengan konteks hidupnya. Penulis melihat ranah budaya sebagai jalan untuk menemukan ruang alternatif bagi pendidikan Kristen. Khusus dalam penelitian ini, peneliti akan mengkaji tradisi perkawinan massarak (harfiah: menyapih, cerai) di Kecamatan Nosu, Kabupaten Mamasa. Massarak adalah tahap akhir dari ritus perkawinan (Pampang, 2013). Bagi orang Mamasa (Toraja), perkawinan bukan hanya menyatukan sepasang pengantin. Perkawinan membentuk jejaring hubungan keluargaan yang lebih besar. Melalui perkawinan diharapkan terjadi regenerasi melalui keturunan, kedamaian (harmoni), kesejahteraan bahkan relasi dan strata sosial (Rumbi, 2020, p. 125).

Dalam pengamatan penulis ada kecenderungan ritus ini dilaksanakan sebatas kebiasaan, tetapi kurang mengangkat nilai-nilai di dalamnya. Atas dasar itu, penulis bermaksud mengkaji nilai-nilai dalam ritual massarak, kemudian 
menganalisisnya untuk pengembangan pendidikan Kristen dalam keluarga. Dalam penelusuruan penulis, belum ada penelitian mengkaji nilai-nilai massarak. Penelitian yang ada hanya menyinggung tempatnya dalam tradisi perkawinan (Pampang, 2013), dan administrasi kependudukan (Yustianto et al., 2020).

Untuk kepentingan pelestarian nilai budaya, mengangkat ulang nilai-nilai budaya merupakan sebuah usaha mewariskan kearifan lokal kepada gene-rasi penerus. Sebaliknya mengabaikan nilai-nilai budaya akan mengaburkan jati diri sebuah suku bangsa. Demikian juga jika ritus hanya menekankan sisi praktis dan kontestasi. Akibatnya nilai-nilai yang dapat bermanfaat sebagai muatan edukasi bagi masyarakat terancam untuk dilupakan. Tradisi mengan-dung nilai-nilai yang dapat memengaruhi kehidupan masyarakat. (Aziz, 2017, pp. 24-25).

\section{Metode}

Penelitian kualitatif adalah penelitian yang bersifat naturalistik. Penelitian kualitatif digunakan untuk mencari dan menemukan pengertian tentang fenomena dalam suatu konteks khusus (Moleong, 2018, p. 5). Pada prinsipnya proses penelitian kualitatif telah dilakukan sejak perencanaan dan berakhir setelah peneliti mengumpulkan data-data, tepatnya menjawab tujuan penelitian. Miles dan Huberman mengelompokkan tahap analisis data dalam penelitian kualitatif yakni reduksi data, penyajian data, dan pengambilan kesimpulan/ verifikasi (Huberman \& Miles, 2009, p. 292). Penyajian data dibuat dengan mendeskripsikan fokus peristiwa yakni cara masyarakat memahami maupun berinteraksi (Yusuf, 2017, p. 350). Data-data yang penulis deskripsikan berangkat dari hasil pengamatan dan wawancara terhadap tokoh-tokoh adat dan gereja di Kecamatan Nosu. Pengamatan yang penulis lakukan berlangsung melalui kehadiran penulis pada acara massarak yang dilakukan oleh warga jemaat. Informan dipilih dengan berbagai alasan: pernah hadir dalam ritual, memiliki peran dalam ritual baik dalam kapasitas sebagai tokoh adat maupun sebagai tokoh gereja. Di samping itu, beberapa informan dianggap dapat memper-lihatkan pergeseran tata cara, makna serta menjelaskan nilai-nilai yang terkan-dung.

\section{Hasil dan Pembahasan}

\section{Pendekatan Budaya dalam Pendidikan}

Pendidikan Kristiani dapat berlangsung pada berbagai konteks kehidupan, baik di sekolah maupun melalui interaksi masyarakat. Tujuan pendidi- 
kan Kristiani ialah mengarahkan umat supaya hidup menurut imannya kepada Allah. Seymour (2016, pp. 14-19) mengelompokkan empat pendekatan yang bisa digunakan dalam pendidikan Kristen yakni transformasi sosial, komunitas iman, perkembangan spiritual dan pengajaran agama. Keempat pendekatan memberi perhatian terhadap proses interpretasi terhadap konteks, teks serta partisipasi atau aksi yang berlandaskan iman Kristiani.

Konteks menyangkut relasi sosial, cara masyarakat berpikir tentang hidup dan budayanya. Melalui proses interpretasi, seseorang dapat mengenali konteks dan menentukan sikap yang tepat. Pazmino (2013, p. 230) memberi perhatian terhadap konteks budaya. Bagi Pazmino tanpa mempertimbangkan budaya, maka kekristenan adalah sesuatu yang abstrak. Kekristenan hadir dalam konteks hidup manusia berbudaya, sehingga umat perlu mendengarkan dan menjalani kebudayaannya. Pazmino (2013, p. 233) mengharapkan agar kekristenan berkomitmen dalam merasakan dan memahami nilai-nilai budaya serta digunakan menyampaikan pesan tentang kehendak Allah kepada manusia.

Merujuk kepada kitab-kitab Injil, Yesus sendiri mempraktekkan hal tersebut dalam pengajaran-Nya. Yesus mendekati budaya untuk memberitakan Kerajaan Allah. Yesus menegaskan bahwa keberadaannya bukan untuk meniadakan hukum Taurat melainkan menggenapi (Mat 5: 17). Hukum Taurat merupakan produk budaya religius bangsa Israel yang tidak ditiadakan oleh Yesus, tetapi digunakan untuk memberi pandangan baru yang sesuai dengan Injil Kerajaan Allah. Menamparampil (2011, p. 52) seorang teolog Katolik India dalam refleksinya terhadap nilai-nilai budaya Asia mengatakan kehadiran Kristus untuk menjamah peradaban manusia, merangsang yang terbaik dalam tradisi serta mengarahkannya menuju kesempuranaan Bapa. Jadi dalam ranah pendidikan Kristen perlu perubahan sikap terhadap kebudayaan dari antipati menjadi penerimaan dan pembaharuan nilai budaya.

Nilai budaya dapat dibedakan berdasarkan polarisasi antara nilai positif dan negatif, serta dari segi urutan kepentingannya (Setiadi et al., 2017, p. 121). Nilai budaya (khususnya yang positif) perlu dikembangkan karena dapat memajukan peradaban yang berkemanusiaan. Ramdani (2018, pp. 2-4) mengingatkan pentingnya pendidikan nilai budaya untuk penguatan karakter bangsa, serta merangsang seseorang menerapkan pengetahuan moral yang berlaku di masyarakat.

Dalam kebudayaan yang tidak mengenal aksara, nilai-nilai budaya diwariskan melalui tradisi lisan baik cerita-cerita rakyat/dongeng, kisah-kisah 
keluarga bahkan nasihat-nasihat. Pada kebudayaan yang mengenal aksara, nilainilai diwariskan melalui tuturan maupun manuskrip. Sama seperti orang lainnya (di Tana Toraja dan Toraja Utara), transmisi pengetahuan, nilai dan praksis pendidikan pada orang Toraja Mamasa umumnya berlangsung dalam keluarga. Sanderan (2020) dalam penelitiannya di Toraja menjelaskan proses pendidikan berlangsung dalam kehidupan komunal sebagai anggota keluarga. Proses pedagogi, andragogi, dan heutagogi di desain melalui berbagai metode dan pola pendidikan yang tidak berbasis kurikulum seperti pendidikan formal (Sanderan, 2020, p. 310). Sejumlah metode pendidikan yang dapat dijumpai pada konteks masyarakat Mamasa yakni menarasikan cerita rakyat, silsilah keluarga, cara menjalani kehidupan, serta memberi nasihat pada kegiatan sosial budaya dan keagamaan.

Penulis menyadari tidak semua nilai budaya dapat diambil atau digunakan bagi dunia pendidikan, misalnya usaha mempertahankan kesenjangan sosial antara bangsawan dan hamba, ketidaksetaraan gender, serta bebagai bentuk penaklukkan yang lain. Nilai budaya yang digunakan ialah niai budaya yang berdampak positif di masyarakat, serta nilai budaya yang bersifat universal.

\section{Ritual Massarak}

Orang Mamasa merupakan sub suku Toraja. Adat-istiadat orang Mamasa dapat diklasifikasikan berdasarkan fungsinya di masyarakat. Masyarakat menyebutnya pemali a'ppa randanan (empat tatanan kebiasaan): (a) Pa'banne-tauan yakni kebiasaan di sekitar perkawinan dan kelahiran; (b) Pa'totiboyongan yakni kebiasaan terkait usaha meningkatkan kesejahteraan khususnya pertanian; (c) $P a^{\prime} b i s u a n$ yakni kebiasaan berkenaan dengan ucapan syukur; (d) Pa'to-matean yakni kebiasaan berkenaan dengan kematian (Stepanus et al., 2019, p. 175).

Buijs seorang antropolog berkebangsaan Belanda, berpendapat ritual perkawinan merupakan ruang penyatuan antara dua kuasa berkat yakni langit dan bumi demi proses regenerasi manusia di bumi. Perempuan menyimbolkan kuasa berkat dari bumi, sedangkan laki-laki menyimbolkan kuasa berkat dari langit, yang ilahi (Buijs, 2009, pp. 207-208). Perempuan dan bumi menyiratkan makna kesuburan. Kehidupan bersumber dan diolah dalam kesuburan. Sedangkan laki-laki dan langit mewakili kuasa ilahi yang adalah sumber kehidupan. Dari perkawinan dua sumber kehidupan diharapkan hadir keturunan.

Tradisi perkawinan di Mamasa awalnya berkembang dalam pengaruh Aluk Todolo, Aluk Tomatua atau Aluk Mapurondo (agama suku). Seiring perpin- 
dahan agama secara besar-besaran dari Alukta ke agama Kristen, maka massarak mengalami penyesuaian pada tata cara, serta makna dan nilai yang diberikan. Ritual massarak mirip dengan ma'pasule barasan di daerah Tana Toraja dan Toraja Utara. Ma'pasule barasan secara harfiah diartikan mengembalikan bakul (Kobong, 2008, p. 63). Ritual dilaksanakan tiga hari setelah acara pernikahan. Dalam ritual semua yang hadir makan bersama, sebagai simbol persekutuan di antara dua keluarga (Sandarupa et al., 2016, p. 19).

Inti ritual massarak ialah mengantarkan kedua pengantin dari rumah orang tua perempuan (tempat berlangsungnya pesta pernikahan) ke rumah orang tua laki-laki. Pada wilayah adat Tandalangngan, tepatnya di Kecamatan Nosu, massarak dilakukan sebagai tanda ungkapan syukur dari pihak laki-laki atas selesainya acara pernikahan (Pangloli, 2021). Masyarakat juga mengunakan istilah yakni disandakalei (harfiah: pakaian yang disiapkan pihak laki-laki dan diberikan kepada istrinya). Dalam massarak tampak sikap saling menghargai di antara keluarga besar, termasuk memberi bagian daging tertentu untuk keluarga perempuan (Andarias, 2021).

Massarak dimulai dengan mengantar pasangan pengantin dari rumah orang tua pengantin perempuan ke rumah orang tua pengantin laki-laki. Dalam proses tersebut hanya ayah dari pengantin perempuan dan anggota kerabat lain yang diperbolehkan mengantar. Sedangkan ibu dari pengantin perempuan tidak diperkenankan ikut. Menurut Pangloli, alasan ini sangat dipengaruhi oleh faktor malu malu (masiri'). Orang tua malu jika terus mengawal anak perempuannya, apalagi jika anaknya pergi dengan suaminya (Pangloli, 2021).

Mereka yang mengantar, khususnya perempuan, menggunakan pakaian adat Mamasa lengkap dengan aksesorisnya. Baju yang digunakan berwarna putih, menggunakan sarung tenun dan sassang (aksesoris pakaian adat Mamasa), sarong belo' (topi adat oleh perempuan), serta sappa dan pangan (tas beserta isinya yakni sirih dan pinang). Pakaian adat menyimbolkan (a) strata sosial atau kekayaan, serta (b) rangkaian acara yang akan dilalui. (c) Sarong belo' menyimbolkan jumlah babi yang akan digunakan selama acara (Pangloli, 2021).

Rombongan disambut dengan suguhan sirih dan pinang (ma'panggan) sebagai simbol rasa hormat (kasianggaran) atas kedatangan anggota keluarga pada rumah tersebut. Penerimaan yang ditunjukkan oleh keluarga laki-laki kepada keluarga perempuan yang datang menunjukkan penghargaan dari pihak laki-laki kepada pihak perempuan (Toding, 2019). 
Selanjutnya pengantin diberikan segelas air untuk diminum bersama. Maknanya berupa penegasan atau pengakuan bahwa mereka sudah satu sebagai suami dan istri. Setelah acara, pengantin tinggal di rumah orang tua laki-laki paling sedikit tiga malam. Selanjutnya mereka bebas tinggal di mana saja tergantung di mana mereka merasa nyaman (Andarias, 2019). Ritus massarak mengandung beragam antara lain:

\section{Nilai Kekeluargaan}

Perkawinan adalah memberi dan menerima pengantin untuk menjadi bagian dari keluarga. Selanjutnya, perkawinan menyatukan dua keluarga besar ke dalam jejaring kekeluargaan yang lebih besar dan kompleks. Ikatan inilah yang menjadi dasar keterlibatan bersama pada berbagai kegiatan keluarga, serta secara khusus pada acara perkawinan dan kematian. Bagi kedua pengantin (keluarga yang baru), massarak merupakan tahap awal untuk membentuk ikatan emosional dan solidaritas sebagai anggota keluarga. Kedua keluarga besar tampak saling membutuhkan, saling terbuka, saling menghargai (Kumba, 2019; Sombo, 2019) serta memiliki keinginan bersama untuk menjaga keutuhan keluarga di tengah masyarakat (Andarias, 2019).

\section{Nilai Presitise dan Penghormatan}

Nilai prestise yang dimaksud ialah usaha mempertahankan reputasi keluarga. Hal ini ada kaitannya dengan kebiasan masa lampau di mana ritual hanya dapat dilakukan oleh mereka yang berstrata sosial tinggi. Namun nilai kehormatan itu mulai bergeser, ditandai dengan memberi kebebasan kepada masyarakat untuk melakukan atau tidak melakukan hal tersebut, serta tidak lagi berdasarkan strata sosial (Andarias, 2021; Pangloli, 2021).

Di sisi lain melalui massarak' sedang dibina sikap kasianggaran (menghargai, menghormati) antar keluarga, bahkan kepada masyarakat atau lingkungannya. Dari hasil pengamatan dan wawancara oleh penulis, nilai penghormatan berulang kali tampil secara simbolik, antara lain: (a) Pengantin tidak dibiarkan untuk pergi sendiri ke rumah orang tua pengantin laki-laki. Mereka diantar oleh keluarga dari pengantin perempuan. Lewat tindakan itu perasaan canggung dan gengsi diredam melalui kesediaan untuk menguatkan komunikasi di antara keluarga. Sebagaimana keluarga laki-laki telah memberi atau menyerahkan anak mereka kepada keluarga perempuan, maka sebaliknya keluarga perempuan memberi atau menyerahkan anak mereka; (b) Sikap keluarga dan 
orang tua pengantin perempuan dalam mengantar pasangan pengantin ke rumah orang tua pengantin laki-laki, tampak orang tua tidak melepas anaknya dengan begitu saja dan menunjukkan sikap balasan tanda penghormatan atas perkunjungan keluarga laki-laki; (c) Penerimaan yang ditunjukkan oleh keluarga penggantin laki-laki melalui penerimaan dan jamuan makan bersama menunjukkan penghormatan kepada tamu.

\section{Nilai Kemandirian}

Tindakan dari ibu pengantin perempuan yang tidak ikut mengantar anak perempuannya ke rumah keluarga barunya, memperlihatkan upaya mendukung kemandirian. Seperti telah disinggung pada pokok bahasan ritual massarak, di balik rasa malu dari orang tua, terdapat usaha untuk melepas anak perempuanya dalam kepercayaan kepada suami sang anak. Hidup mandiri merupakan cita-cita bagi semua orang tua dalam membesarkan anak-anaknya.

\section{Nilai Kasih}

Dalam ritual massarak, orang tua memberi nasihat kepada pengantin baru. Umumnya nasihat berisi pesan agar mereka saling mengasihi keluarga yang baru. Sipakaboroko lan pa'banua-nuammu dewata tottong la ukkambi'ko artinya kedua mempelai harus saling mengasihi di dalam rumah tangga mereka dan Tuhan yang akan menyertai (Kumba, 2019). Orang tua menasihatkan bahwa keputusan berumah tangga merupakan tanggung jawab yang harus dilaksanakan. Nasihat supaya hidup dalam kasih merupakan pondasi bagi setiap hubungan yang dikehendaki oleh Tuhan. Pola hidup itu memberi daya dukung bagi keluarga baru dan keluarga besarnya untuk menciptakan kehidupan yang harmonis.

\section{Nilai Solidaritas}

Solidaritas terlihat melalui partisipasi anggota masyarakat dalam menyukseskan massarak. Baik mempersiapkan konsumsi, tempat kegiatan maupun melayani tamu. Partisipasi ini berangkat dari kesadaran untuk saling meringankan, juga dilaksanakan tanpa mengharap imbalan (Andarias, 2019).

Berdasarkan uraian tentang nilai-nilai tersebut dapat dikatakan bahwa massarak memperhatikan aspek sosial (relasi). Relasi dengan sesama manusia dalam kerangka membentuk, mengukuhkan serta menjaga keutuhan keluarga. Relasi dengan Tuhan terlihat melalui implementasi nilai-nilai kebaikan maupun harapan supaya keluarga terus diberkati oleh Tuhan. 


\section{Nilai-nilai Massarak dari Segi Iman Kristen}

Mengingat penelitian ini berusaha menggunakan nilai budaya untuk pendidikan Kristen, maka nilai budaya perlu diinterpretasi dengan memberi penguatan dari segi iman Kristen. Groome (2011, p. 81) mengemukakan tujuan pendidikan Kristen ialah mengajarkan tiga dimensi iman yakni percaya, mempercayakan dan melakukan. Pendidikan iman tidak hanya terarah pada pembentukan kognitif tetapi untuk menggerakkan semua orang menyatakan ajaran dan kehendak Allah dalam praksis hidup beriman.

Pendidikan Kristen dengan menggunakan nilai budaya penulis artikan sebagai usaha mendengarkan kearifan lokal masyarakat serta menggunakannya sebagai cara untuk mengajarkan iman Kristen. Pada konteks ritual massarak beragam nilai positif yang dimiliki mengungkapkan gagasan cara hidup dalam keluarga. Nilai-nilai tersebut hasil olah rasa, cipta dan karsa dalam rangka menciptakan harmoni dalam keluarga yang baru terbentuk baik pengantin baru maupun ikatan kekeluargaan yang lebih besar. Nilai-nilai budaya yang hendak digunakan untuk pendidikan bagi keluarga Kristen harus diperkuat dengan gagasan teologis yang sifatnya membaharui dan menguatkan, sehingga keluarga Kristen kokoh dalam budaya dan imannya.

Nilai kekeluargaan pada ritual massarak' merupakan usaha mendekatkan hubungan di antara keluarga besar dengan sistem pertukaran anggota keluarga (resiprokal). Proses memberi dan menerima di antara keluarga dilakukan melalui pertukaran yang menggembirakan. Tidak ada rasa kehilangan atau kekurangan karena anggota keluarganya (pengantin) ditarik masuk pada kelompok keluarga besar yang lain. Oleh karena sifatnya yang menggembirakan, maka ikatan emosional yang mempersatukan keluarga besar menjadi semakin kuat.

Tindakan mengantar pengantin ke rumah orang tua pengantin laki-laki, bukan untuk menunjukkan sistem perkawinan patriarki melainkan penerimaan pengantin perempuan diterima sebagai bagian dari anggota keluarga yang baru. Justru memperlihatkan kesetaraan gender, sebagaimana kajian-kajian teologi feminis. Perempuan tidak diberlakukan sebagai objek, tetapi ia diangkat dalam kesetaraan dengan laki-laki (sesama subjek) yang dengan tegas diung-kapkan dalam penyambutan pada keluarga suaminya. Hal ini berbeda dengan pola perkawinan dalam tradisi bangsa Israel. Pertama, laki-laki meninggalkan orang tua untuk bersatu dengan istrinya (Kej. 2: 24). Menurut Stanislaus (2017, p. 24), Allah memberikan daya tarik kodrati yang cukup besar kepada manusia sehingga ia mampu memutuskan ikatan yang begitu kuat dengan orang tuanya 
demi membentuk ikatan yang baru dalam kemandirian dengan istrinya. Kedua, perempuan atau istri diantar ke rumah orang tua suaminya karena bersoal jawab terkait keturunan dan pembagian harta warisan. Masyarakat Israel bersifat patrilineal, di mana pertimbangan terkait hal tersebut dinilai dari sudut laki-laki dan dengan demikian turut memperkuat kedudukan laki-laki dalam perkawinan (Stanislaus, 2017, p.32). Pada tradisi perkawinan lain dari bangsa Israel, pengantin perempuan diantar kepada orang tua pengantin laki-laki. Misalnya Ribka yang dibawa kepada Abraham (Kej. 24).

Pesan-pesan pernikahan Kristen penting untuk memberi perhatian pada cara hidup keluarga baru, legalitas, kesatuan dan cara menata hidup rumah tangga (Ef. 6:1-3; Kol. 18-20). Patty, Wenno dan Tousita (2020, p. 214) dalam penelitiannya terhadap hukum atau tata kerumahtanggaan (haustafel) pada kitab Efesus (6:1-19) menemukan nilai-nilai yang dapat digunakan bagi pendidikan karakter dalam keluarga yakni nilai kebenaran, kasih dan ketaatan, penghormatan, persaudaraan, keadilan dan kesetaraan, saling melayani, dan kehidupan yang damai dan harmonis. Gagasan ini melengkapi pemahaman nilai budaya bahwa pembentukan keluarga bukan untuk memecah belah, tetapi mendorong penerimaan terhadap komunitas lain dalam suasana ramah dan kekeluargaan.

Sering kali konflik orang tua dengan anak-anaknya (keluarga baru) dipicu oleh karena terhambatnya komunikasi antara keluarga anak dengan orang tuannya. Kisah ketegangan antara orang tua dengan menantu ditemukan juga dalam kisah Laban dan Yakub. Laban terus mencari alasan supaya Yakub bersama istri dan anaknya tidak meninggalkannya. Tampak Laban takut membiarkan anak-anaknya menata rumah tangga sendiri (Kej. 30:27-31). Ketegangan atau perselisihan berakhir dengan baik, yang ditandai dengan perjanjian (Kej. 31:4850). Pada kisah lain kita, menemukan hubungan yang harmonis antara mertua dan menantu, seperti pada kisah Naomi dan Rut. Rut setia mendampingi mertuanya sekalipun suaminya sudah meninggal. Rut menunjukkan hubungan emosional yang sangat erat dengan mertuanya (Rut 1:16-17).

Degradasi nilai karena kurangnya rasa hormat anak kepada orang tua dan atau sebaliknya orang tua kurang menghargai anaknya, ikut memicu konflik dalam keluarga, kekerasan dalam rumah tangga, bahkan pelecehan seksual bahkan penelantaran anak dan lansia. Tentu hal ini sesuatu yang mengkuatirkan karena pertanda bahwa nilai saling menghormati mulai memudar.

Nilai penghormatan yang dijumpai pada ritual massarak, dapat dikata-kan mewakili cita rasa Timur atau Asia tentang relasi yang ideal antara anak-anak 
dan orang tua, antara generasi muda dengan generasi tua. Orang tua atau tuatua merupakan teladan dalam sikap dan tindakan. Itu sebabnya mereka selalu mendapat tempat istimewa yakni sebagai pemimpin pada berbagai kegiatan sosial maupun religius. Mengenai tugas dan fungsi itu mendapat aspek legitimasi dalam Alkitab, itu sebabnya peran tua-tua seringkali dikisahkan. Di samping itu, hukum taurat juga mengingatkan tentang pentingnya anak-anak menghormati orang tua, dan bagian haustafel pada Efesus dan Kolose menata bagai sikap hormat ditunjukkan oleh suami, istri dan anak-anak.

Nasihat untuk saling mengasihi sesama merupakan salah satu nilai keutamaan yang ditekankan Yesus Kristus. Kasih harus dinyatakan pada berbagai aspek kehidupan. Nasihat yang diberikan orang tua pada pengantin baru seperti meletakkan fondasi bagi kehidupan rumah tangga. Dengan mengingatkan tentang kasih, maka setiap pasangan harus mengesampingkan ego dan saling menerima satu dengan yang lain.

Solidaritas merupakan tanda kepedulian satu dengan yang lain. Praktek yang ditunjukkan oleh orang Mamasa menunjukkan corak kehidupan mereka yang kolektif. Lewat keterlibatan bersama sangat jelas bentuk kepedulian satu dengan yang lain. Gaya hidup kolektif yang ditunjukkan sejalan dengan iman Kristen. Melalui pola hidup ini umat bisa saling menerima satu dengan yang lain, berbelarasa dan terutama berada di arah yang benar untuk mewujudkan kesatuan sebagai tubuh Kristus.

\section{Penerapan Nilai}

Nilai-nilai yang ditemukan dalam ritual massarak dan telah direinterpretasi berdasarkan iman Kristen menjadi materi pendidikan yang baik. Sebagai muatan nasihat dari orang tua atau tua-tua dalam keluarga saat memberi pesanpesan pernikahan kepada pengantin maupun kepada semua yang hadir dalam acara massarak. Nasihat tentang cara menjalani kehidupan, bahwa setiap keluarga tidak bisa dilepaskan dari relasi dengan keluarga besarnya. Relasi dapat dipertahankan dengan baik apabila memperhatikan nilai kekeluargaan, penghormatan, kemandirian, kasih dan solidaritas baik dengan sesama anggota keluarga, maupun masyarakat. Lebih lanjut, nilai-nilai itu dapat digunakan sebagai bahan pemberitaaan majelis gereja ketika melaksanakan ibadah pada ritual massarak. Selain itu, nilai-nilai positif yang terkandung dapat digunakan oleh gereja sebagai materi pada perkunjungan-perkunjungan pastoral keluarga Kristen. 


\section{Rekomendasi untuk Penelitian Lanjutan}

Berdasarkan temuan penelitian penulis serta dalam rangka pengembangan nilai pendidikan, penulis merekomendasikan supaya diadakan penelitian pengembangan tentang pemahaman keluarga (rumah tangga) yang baru mengenai nilai-nilai yang terkandung dalam ritual massarak.

\section{Kesimpulan}

Dari penelitian terhadap nilai-nilai yang terkandung dalam ritual massarak, penulis menemukan nilai kekeluargaan, nilai prestise, nilai penghormatan, nilai kemandirian, kasih dan solidaritas. Nilai prestise tidak dapat dilanjutkan bagi pendidikan Kristen karena hal itu bermaksud menciptakan atau mempertahankan kelas-kelas di masyarakat, serta berpotensi menimbulkan masalah sosial lainnya. Sedangkan nilai-nilai yang lain dapat digunakan setelah memperkuatnya dengan pokok-pokok iman Kristen. Nilai-nilai itu dapat menjadi materi pendidikan bagi keluarga Kristen yang disampaikan selama acara yang berlangsung (nasihat orang tua dan pemberitaan atau khotbah gereja), tetapi juga diteruskan sebagai materi perkunjungan pastoral pada keluarga. Tujuannya mengingatkan mengenai komitmen dan cara hidup bersama dengan orang tua dan rumpun keluarga besar.

\section{Daftar Rujukan}

Andarias. (2019). Wawancara oleh Penulis.

Andarias. (2021). Wawancara oleh Penulis.

Antone, H. S. (2010). Pendidikan Kristiani Kontekstual: Mempertimbangkan Realitas Kemajemukan Dalam Pendidikan Agama. BPK Gunung Mulia.

Aziz, S. (2017). Tradisi Pernikahan Adat Jawa Keraton Membentuk Keluarga Sakinah. Ibda' Jurnal Kebudayaan Islam, 15(1), 22-41.

Buijs, K. (2009). Kuasa Berkat Dari Belantara dan Langit: Struktur dan Transformasi Agama orang Toraja di Mamasa Sulawesi Barat. Inninawa.

Groome, T. H. (2011). Christian Religious Education. BPK Gunung Mulia.

Huberman, A. M., \& Miles, M. B. (2009). Manajemen Data dan Metode Analisis. In Norman K.Denzin dan Yvonna S. Lincoln (Ed.), Handbook Of Qualitative Research (pp. 591-612). Pustaka Pelajar.

Karnawati, K., \& Widodo, P. (2019). Landasan Filsafat Antropologi-Teologis Dalam Pengembangan Kurikulum Pendidikan Kristen. Evangelikal: Jurnal Teologi Injili Dan Pembinaan Warga Jemaat, 3(1), 82-89. https://journal.sttsimpson.ac.id/index.php/EJTI/article/view/127

Kobong, T. (2008). Injil dan Tongkonan: Inkarnasi, Kontekstualisasi, Transformasi. BPK Gunung Mulia. 
Kumba, P. (2019). Wawancara oleh Penulis.

Lauterboom, M. (2019). Dekolonialisasi Pendidikan Agama Kristen di Indonesia. Indonesian Journal of Theology, 7(1), 88-110.

Menamparampil, T. (2011). Nilai-nilai Asia Bagi Bangsa Manusia. In P. B. Kleden \& R. Mirsel (Eds.), Menrobos Batas Merobohkan Prasangka Jilid 1. Ledalero.

Moleong, L. J. (2018). Metodologi Penelitian Kualitatif. Rosda Karya.

Pampang, D. (2013). Tatanan Kebiasaan Adat Pitu Ulunna Salu Kondosapata Uai Sapalelean. Dinas Kebudayaan dan Pariwisata.

Pangloli, R. (2021). Wawancara Oleh Penulis.

Patty, F. N., Wenno, V. K., \& Toisuta, F. A. (2020). Keluarga dan Pendidikan Karakter: Menggali Implikasi Nilai-nilai Hausetafel dalam Efesus 6:1-9. KURIOS (Jurnal Teologi Dan Pendidikan Agama Kristen), 6(2), 202. https:/ / doi.org/10.30995/kur.v6i2.155

Pazmino, R. W. (2013). Fondasi Pendidikan Kristen (D. Pranolo \& Yanti (eds.)). BPK Gunung Mulia.

Ramdani, E. (2018). Model Pembelajaran Kontekstual Berbasis Kearifan Lokal Sebagai Penguatan Pendidikan Karakter. Jurnal Pendidikan Ilmu-Ilmu Sosial, 10(1), 1-10.

Rumbi, F. P. (2020). Analisis Teologis Makna Ossoran dalam Pendidikan Keluarga. In B. J. Pakpahan (Ed.), Teologi Kontekstual dan Kearifan Lokal Toraja (pp. 125-141). BPK Gunung Mulia.

Salenusa, B. J. M. (2017). Perdamaian dalam Bingkai Pendidikan Multikultural Berbasis Karakter Hidop Orang Basudara di Kota Ambon. In Y. B. Setiawan, N. Souisa, S. Gasperz, \& R. Lesawengan (Eds.), Perdamaian dan Keadilan (pp. 159-176). BPK Gunung Mulia.

Sandarupa, S., Petrus, S., \& Sitoto, S. (2016). Kambunni': Kebudayaan Tallu Lolona Toraja (N. J. Saleh \& E. B. M (eds.)). De La Macca.

Sanderan, R. (2020). Heuristika dalam Pendidikan Karakter Manusia Toraja Tradisional. BIA': Jurnal Teologi Dan Pendidikan Kristen Kontekstual, 3(2), 306327. https:/ / doi.org/10.34307/b.v3i2.213

Setiadi, E. M., Hakam, K. A., \& Effendi, R. (2017). Ilmu Sosial dan Budaya Dasar (3rd ed.). Kencana.

Seymour, J. L. (2016). Pendekatan-pendekatan Kristiani. In J. L. Seymour (Ed.), Memetakan Pendidikan Kristiani: Pendekatan-pendekatan Menuju Pembelajaran Jemaat (pp. 1-20). BPK Gunung Mulia.

Sidjabat, Binsen S. (2019). Meretas Polarisasi Pendidikan Kristiani: Sebuah Pengantar tentang Arah Pendidikan Kristiani di Gereja, Akademia, dan Ruang Publik. Indonesian Journal of Theology, 7(1), 7-24.

Sidjabat, Binsen Samuel. (2019). Kerangka Kurikulum Pendidikan Agama Kristen Berbasis Karakter di Perguruan Tinggi. Jurnal Jaffray, 17(1), 73-90. https://doi.org/10.25278/jj71.v17i1.314

Sombo, G. (2019). Wawancara Oleh Penulis.

Stanislaus, S. (2017). Perkawinan Dalam Kitab Suci Perjanjian Lama. Logos, Jurnal Filsafat-Teologi, 14(2), 17-51.

Stepanus, Lattu, I. Y. M., \& Tampake, T. (2019). Ritual, Ruang Bersama, dan 
Rekonsiliasi Masyarakat Lokal di Mamasa, Sulawesi Barat. Religio:Jurnal Studi Agama-Agama, 9(2), 170-196.

Susanta, Y. K. (2020). Menuju Pendidikan Kristiani yang Bersahabat di Tengah Heterogenitas Agama. Jurnal Teologi “Cultivation," 4(2), 56-79.

Tanduklangi, R. (2020). Analisis Tentang Tujuan Pendidikan Agama Kristen (PAK) Dalam Matius 28:19-20. PEADA': Jurnal Pendidikan Kristen, 1(1), 4758. https:/ / doi.org/10.34307/ peada.v1i1.14

Toding, T. (2019). Wawancara Oleh Penulis.

Yustianto, Bahri, S., \& Juharni. (2020). Perkawinan Adat Mamasa Studi Administrasi Kependudukan di Luar Nikah (Perda Kabupaten Mamasa Nomor 5 Tahun 2017). Jurnal Paradigma Adminsitrasi Negara, 3(1), 17-26.

Yusuf, M. (2017). Metode Penelitian Kualitatif, Kuantitatif dan Penelitian Gabungan. Kencana. 